\title{
Childhood Malignant Kidney Neoplasm
}

National Cancer Institute

\section{Source}

National Cancer Institute. Childhood Malignant Kidney Neoplasm. NCI Thesaurus. Code C123907.

A malignant neoplasm that affects the kidney and occurs in childhood. 